\title{
O MOVIMENTO INDÍGENA E OS ASPECTOS RELIGIOSOS DA LUTA GUARANI: ENSAIO FOTOGRÁFICO DOS NANDERU'I DAS TERRAS RETOMADAS NO OESTE DO PARANÁ
}

\author{
Paulo Humberto Porto Borges ${ }^{1}$
}

\begin{abstract}
O perigo ameaça tanto a existência da tradição como os que a recebem. Para ambos, o perigo é o mesmo: entregar-se ás classes dominantes, como seu instrumento. Em cada época, é preciso arrancar a tradição ao conformismo, que quer apoderar-se dela. Pois o Messias não vem apenas como salvador; ele vem também como o vencedor do Anticristo. $O$ dom de despertar no passado as centelhas da esperança é privilégio exclusivo do historiador convencido de que também os mortos não estarão em segurança se o inimigo vencer.
\end{abstract}

(W. Benjamin)

Uma guerra vem sendo travada no oeste do Paraná: uma violenta disputa entre a força econômica do agronegócio e pequenas áreas retomadas pelas diversas comunidades Guarani, denominadas por eles como "Tekoa Jevy". Atualmente o oeste do Paraná possui 19 aldeamentos Guarani não reconhecidos pelo Estado que teimam em resistir as fazendas de soja da região nos municípios de Itaipulândia, Santa Helena, Terra Roxa e Guaíra. A grande concentração destas pequenas comunidades se encontram em Terra Roxa e Guaíra onde se localizam 15 áreas retomadas. E neste conflito desigual o papel dos rezadores Guarani, dos

\footnotetext{
${ }^{1}$ Doutor em Educação pela UNICAMP, docente do curso de Pedagogia da UNIOESTE e coordenador do Observatório Social dos Povos Indígenas do Oeste do Paranã www.oguataregua.com.br. Endereço eletrônico: liliamfpb@gmail.com.
} 
xamõi tem sido decisivo. Não é de hoje que a profunda e profética religiosidade Guarani tem sido o grande esteio e fio condutor da permanência histórica deste povo.

Ainda no início da conquista espanhola foram os velhos sacerdotes os principais opositores contra as hordas europeias, invariavelmente em defesa dos antigos costumes e tradições. Um destes profetas foi o Guarani Juan Cuara que já em 1625 andava pelo Paraná exortando sua gente a permanecerem fiéis aos antigos: “(...) Vivid (...) segun las antiguas costumbres, entre bailes y libaciones, celebrando la memoria de los antepasados, no adoreis las imágenes de los santos: tenedme por vuestra deidad; si no hacéis esto, haré que os veáis en el Paraná convertidos en y ranas" (CHAMORRO, 1998).

Juan Cuara via nos missionários um perigo a tradição, assim como suas estranhas práticas religiosas, e afirmava que o sal do batismo era um veneno, o óleo da crisma uma mancha, a confissão não passava de uma maneira de saber da vida dos indígenas para melhor enfraquecê-los e a monogamia uma forma de evitar que os Guarani se propagassem e se multiplicassem. E, caso, seus patrícios ignorarem seus apelos, Juan Cuara ameaçava transformá-los em rãs e sapos.

Segundo Graciela Chamorro, entre 1545 e 1660, ocorreram aproximadamente 24 grandes levantes indígenas de caráter contestatório religioso, a cifra é significativa se levarmos em conta que ele representa quase a metade dos 50 levantes registradas contra o domínio espanhol entre 1537 e 1735 na antiga província do Paraguai.

Ainda segundo Chamorro, o último grande movimento guarani, no final do século XVII, embora se erguesse contra símbolos e práticas jesuíticas, seu principal alvo o sistema colonial, "seu sistema de poder e modos de produção". Durante o ano que durou o levante (1660 - 1661), o índio batizado Rodrigo Yaguariguay manteve seu cacicado como “corregedor" de sua gente, incentivando, sempre quando possível, a subversão aos espanhóis. Com sua gente atacou e sitiou a casa do governador matando todos que conseguiu, "e aos que não puderam matar, forçaram a fugir" (CHAMORRO, 1998).

Talvez este último levante demostre uma possível mudança nas estratégias de resistência indígena - em vez de combater os jesuítas e suas práticas religiosas, os rezadores e profetas guarani apontavam sua ira contra as engrenagens coloniais.

O contato com as sociedades européias ocasionou um rearranjo na perspectiva histórica dos povos indígenas, desde a necessidade de interagir com o europeu a importância de elaborar respostas aos novos acréscimos culturais e econômicos. $\mathrm{O}$ mundo não é mais o mesmo e as profecias se realizam de formas não previstas, seus povos encontram-se ilhados e 
ocupados tanto culturalmente como militarmente. O poder desagregador que a ideologia dominante possui sobre as culturas minoritárias apresenta-se como o triunfo da história do conquistador que desfila com seus exércitos em marcha, os mesmos que esmagaram (e esmagam) estas culturas e esmagarão novamente se for preciso. É nesse quadro que a função dos mais velhos torna-se mais premente quanto mais profundo for o ferimento civilizatório. A eles, detentores da memória e da religiosidade de seus grupos cabe a importante tarefa de salvaguardar o costume dos antigos e garantir a perpetuação de seu povo, assim como o de elaborar e traçar novas estratégias. E não se trata mais de serem apenas guardiões da memória, mas também aqueles que comandarão a resistência frente as terríveis e cada vez mais constantes ameaças oriundas da sociedade não-índia.

Este breve ensaio fotográfico tem como objetivo render uma homenagem e dar visibilidade aos rezadores Guarani do oeste do Paraná, em especial das chamadas áreas retomadas. Eles têm constituído a linha de frente de resistência cultural e física destas pequenas comunidades em relação às ameaças e ao discurso de ódio que vem grassando em torno deles. E neste caso os sacerdotes Guarani nos lembram a figura do historiador em Walter Benjamin que tem a sagrada função de vencer o "anticristo" que vem travestido de esquecimento e da ausência da memória. Neste caso específico, estes rezadores lutam contra o desterro físico e espiritual de seu povo, que inevitavelmente acontecerá se o inimigo vencer.

Afinal, o que são os xamõi Guarani senão historiadores e guardiões da tradição e de toda a memória coletiva de seu povo, ainda que a partir de uma perspectiva religiosa e mítica?

\section{Bibliografia}

BENJAMIN, Walter. Magia e tecnica, arte e política. São Paulo: Brasiliense, 1994.

CHAMORRO, Graciela. A espiritualidade Guarani: uma teologia ameríndia da palavra. São Leopoldo: Sinodal, 1998. 


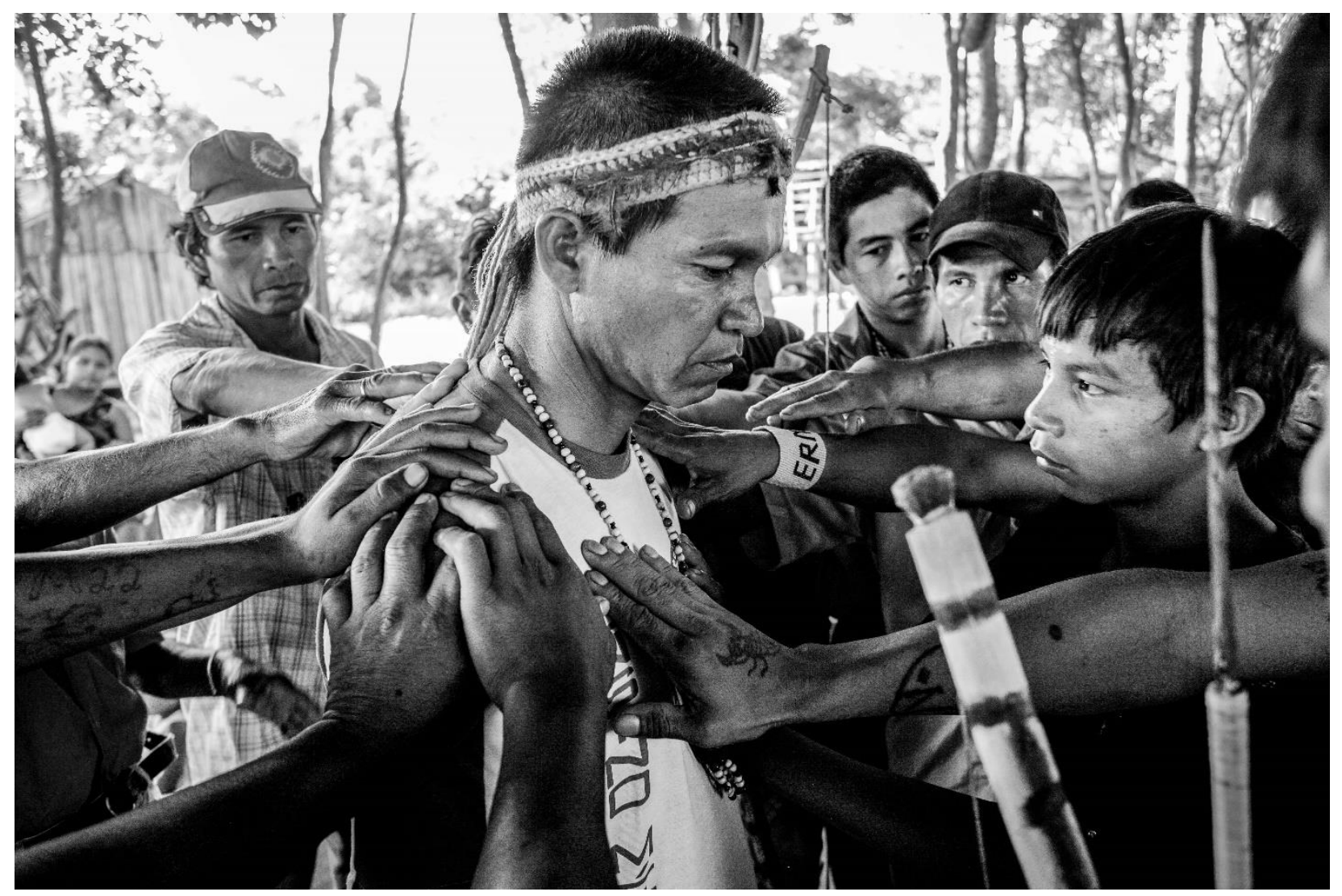

Cacique e xamõi Raul Medina no Tekoa Yvyraty Porã no Município de Terra Roxa.

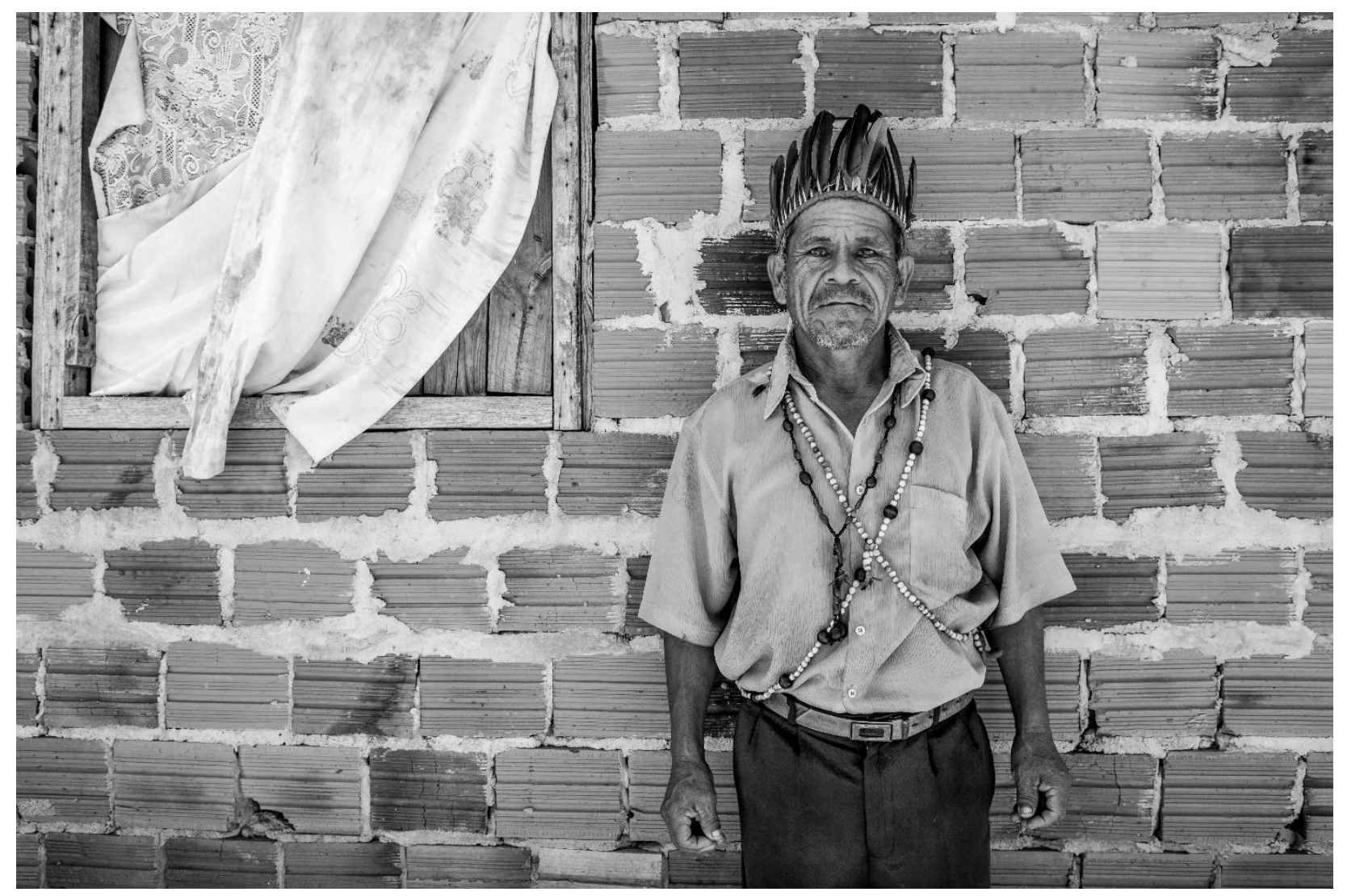

Cacique e xamõi Raul Medina no Tekoa Yvyraty Porã no Município de Terra Roxa. 


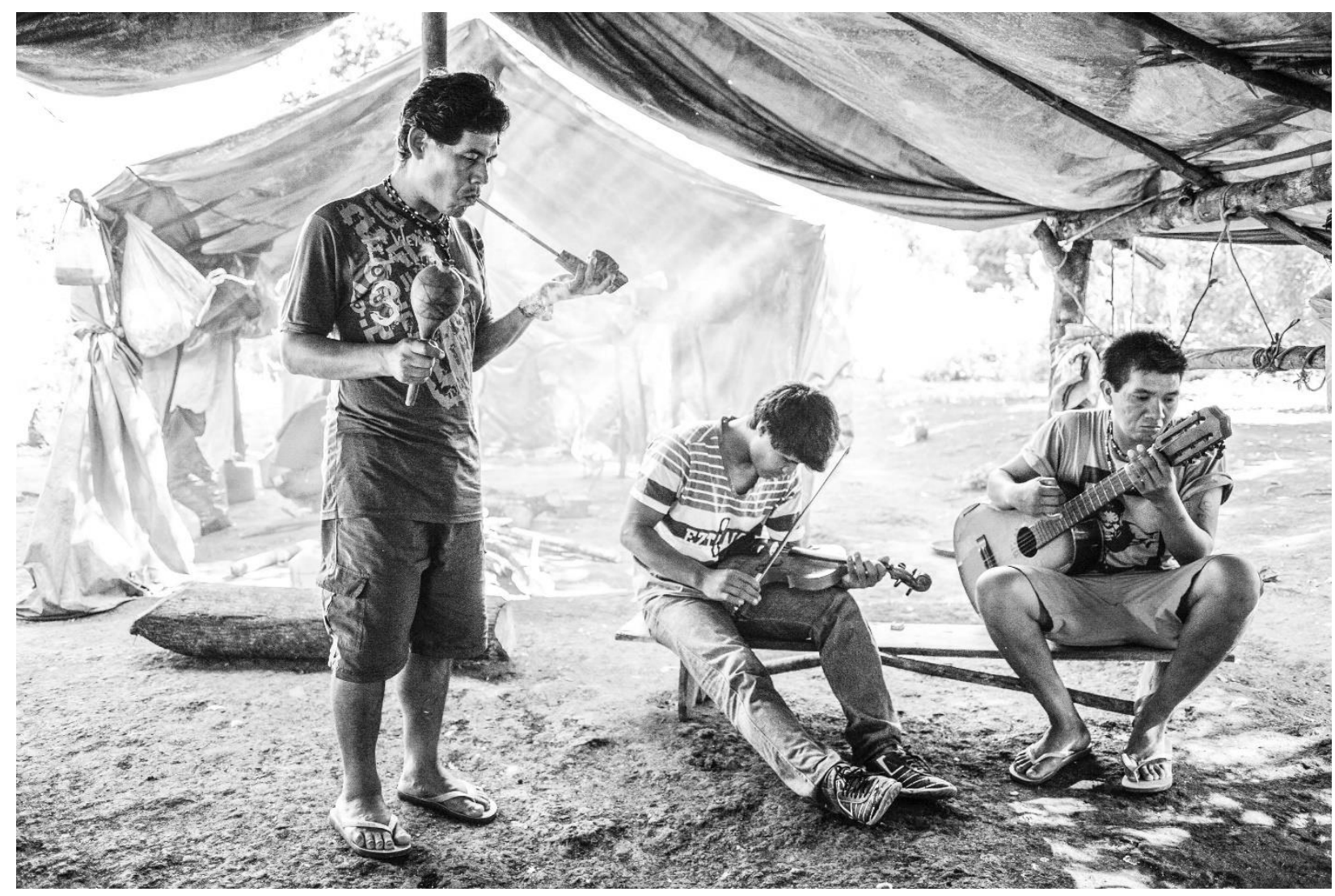

Claudio Bogado na comunidade Tekoa Mokoi Joegua organizando o início da reza.

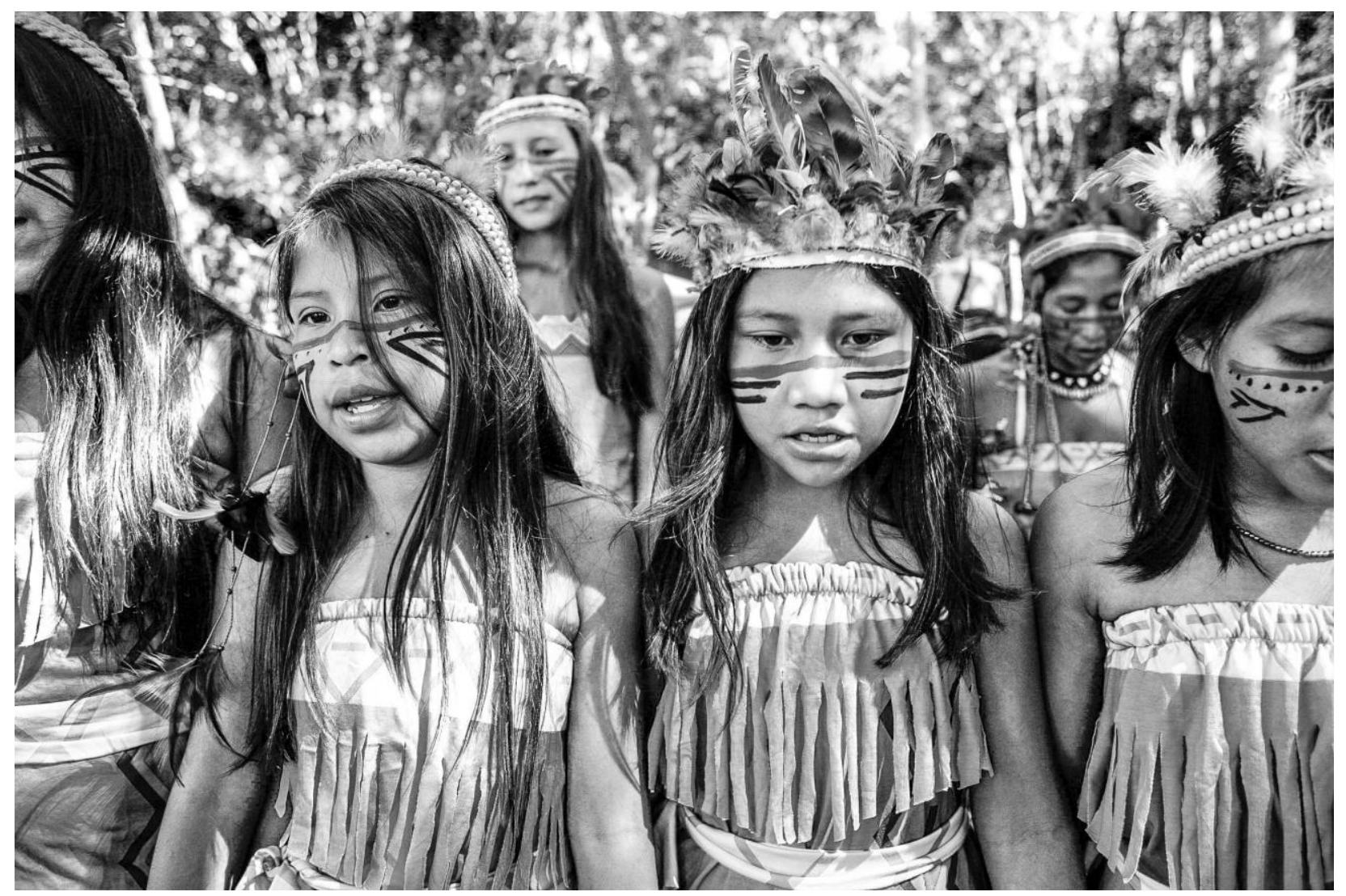

Coral Guarani na comunidade de Tekoa Aty Mirim no Município de Itaipulândia. 


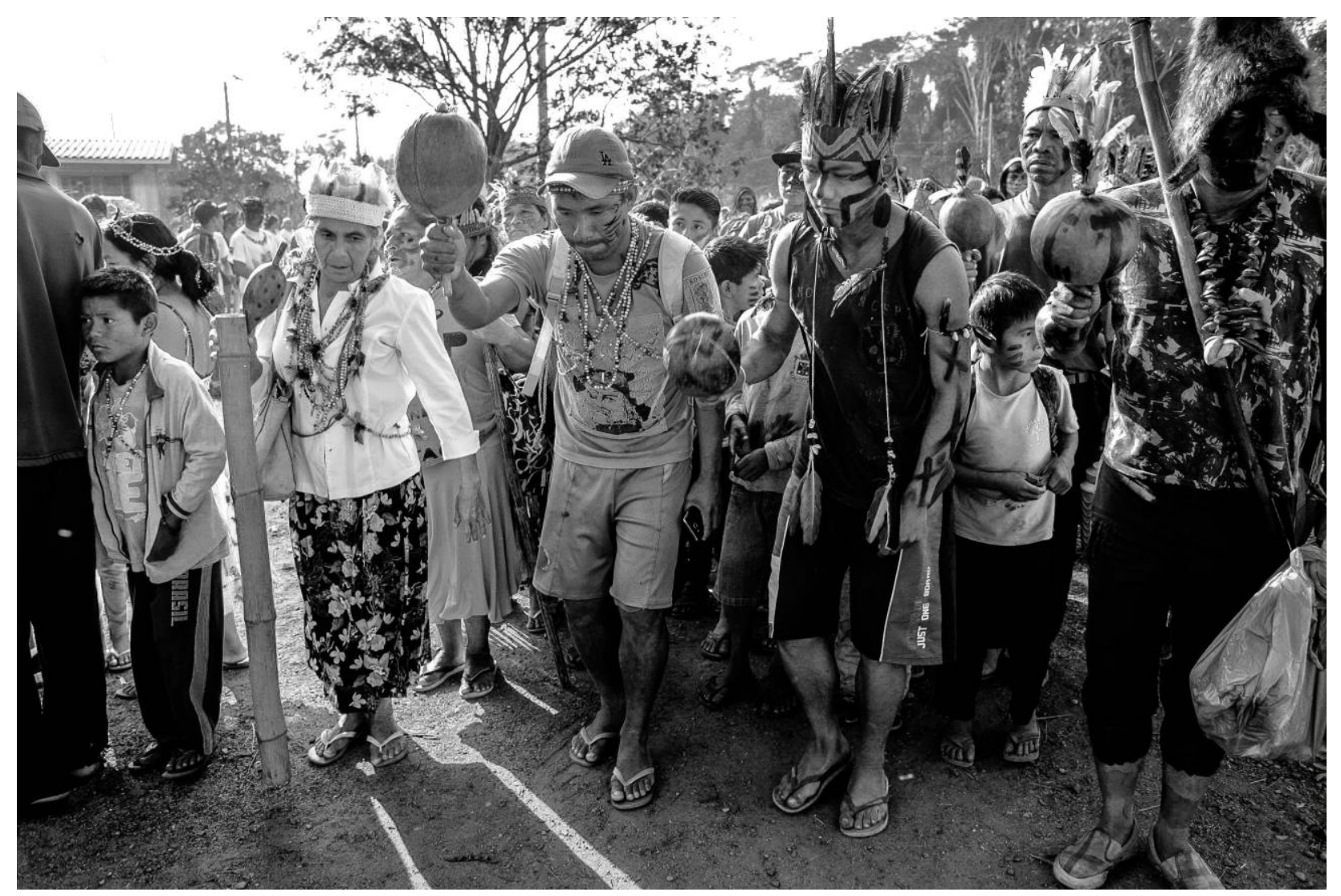

Manisfestação em Guaira em defesa das terras e direitos indígenas.

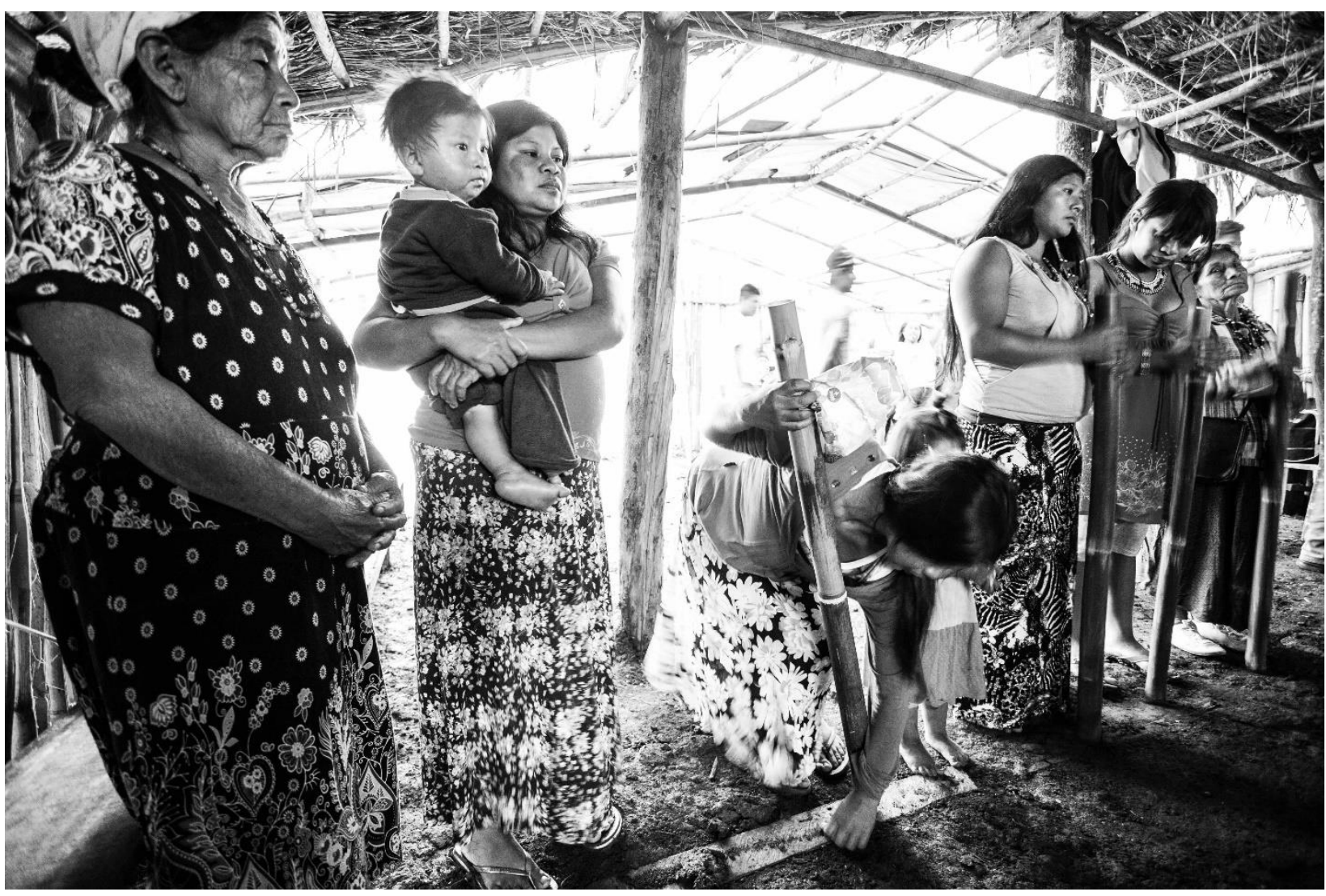

Mulheres Guarani na casa de reza do Tekoa Vy'a Renda - Município de Santa Helena 


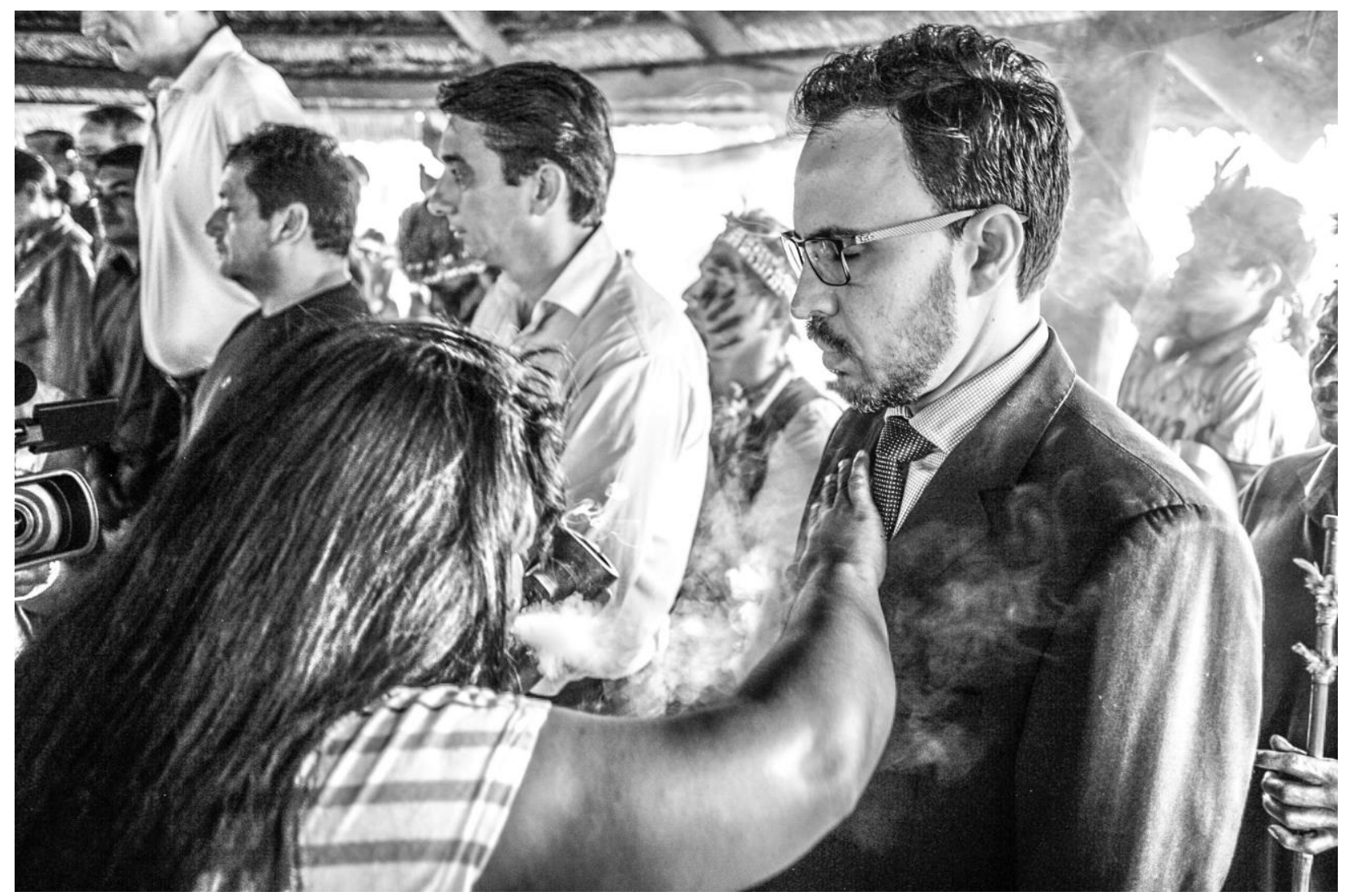

Promotor do MPF de Guaira Dermeval Vianna sendo abençoado pelos xamõi Guarani no Tekoa Marangatu - Município de Guaira.

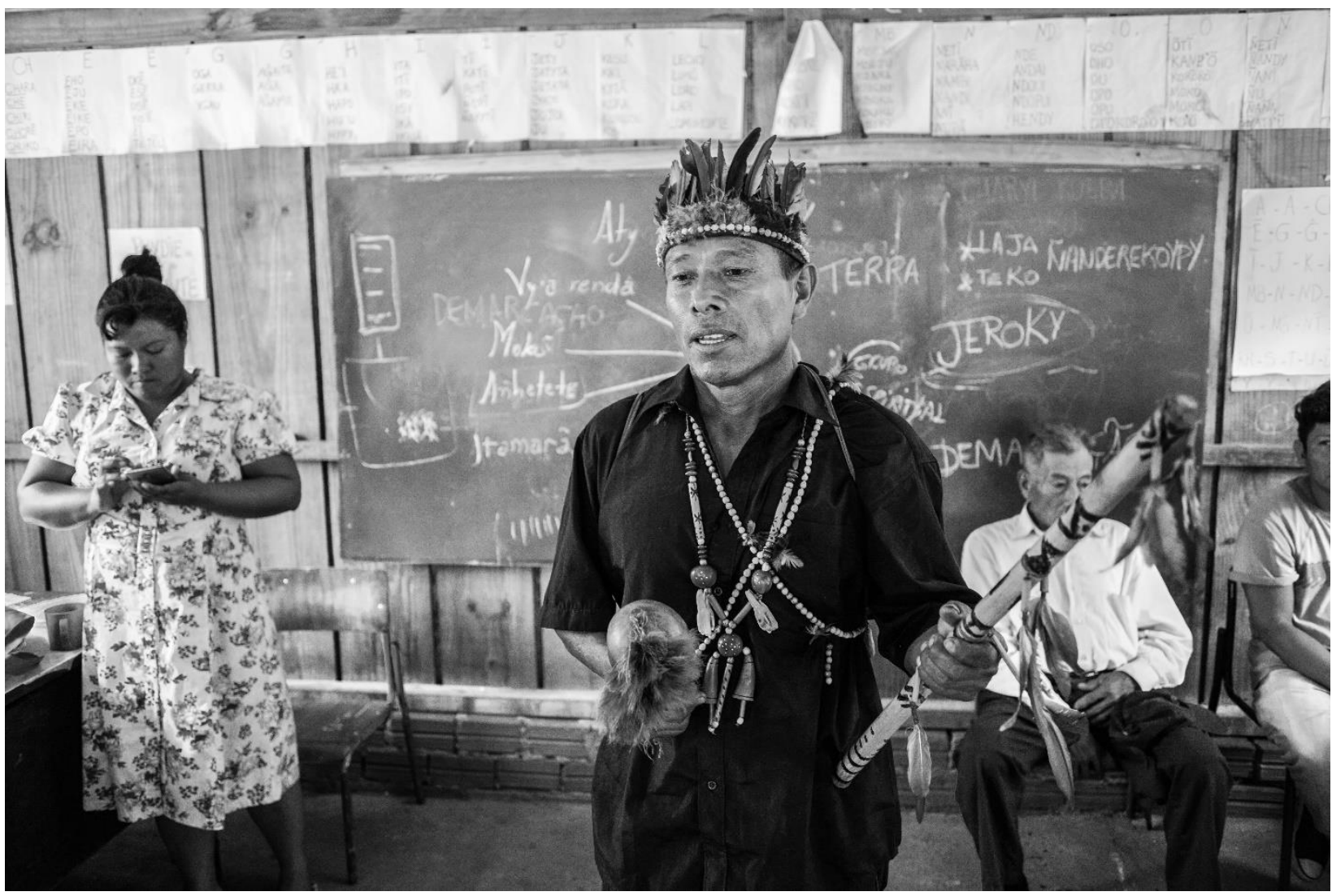

Reunião de rezadores no Tekoa Y Hovy - Município de Guaira 


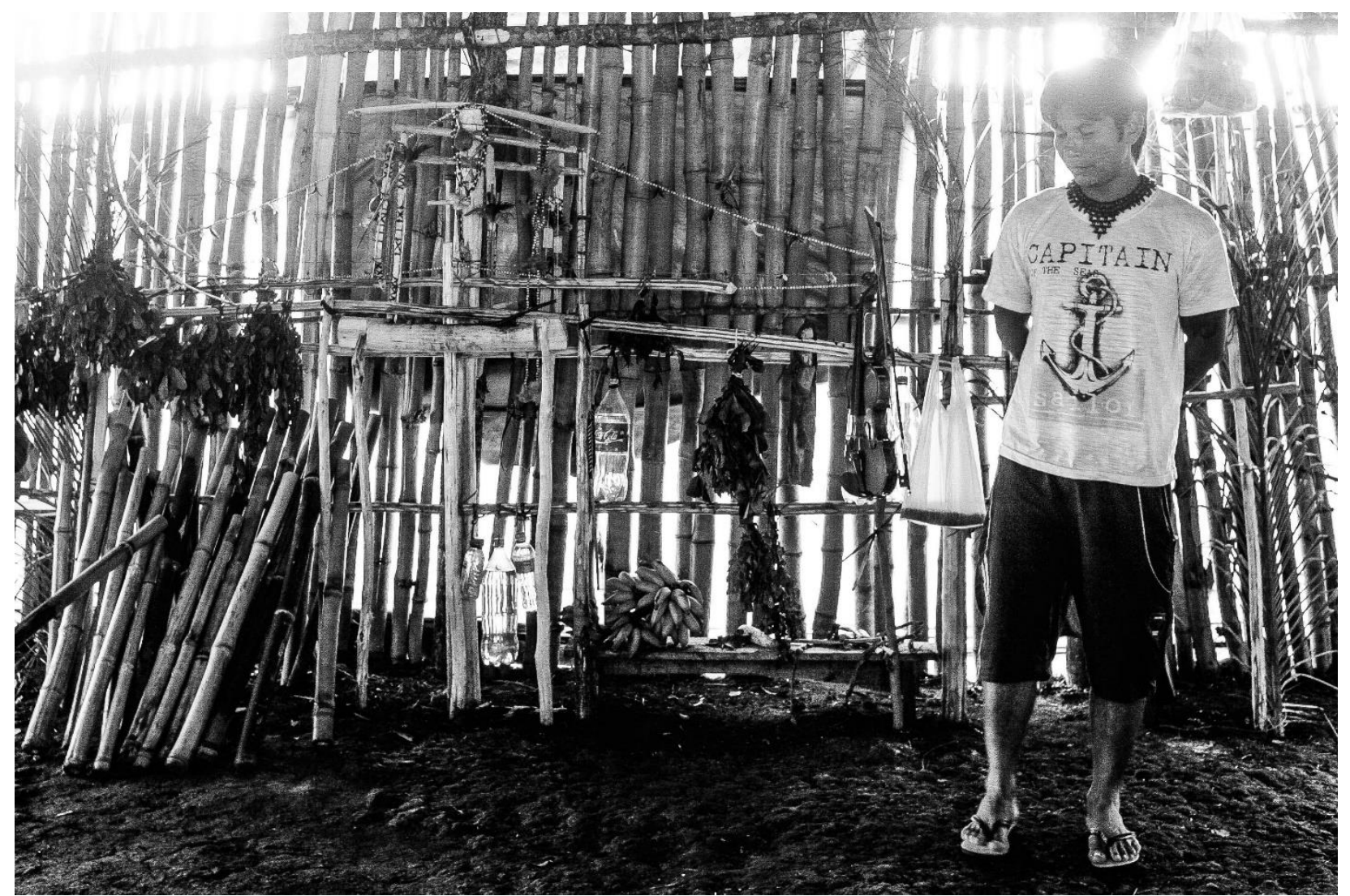

Reunião na casa de reza do Tekoa Vy'a Renda no Município de Santa Helena.

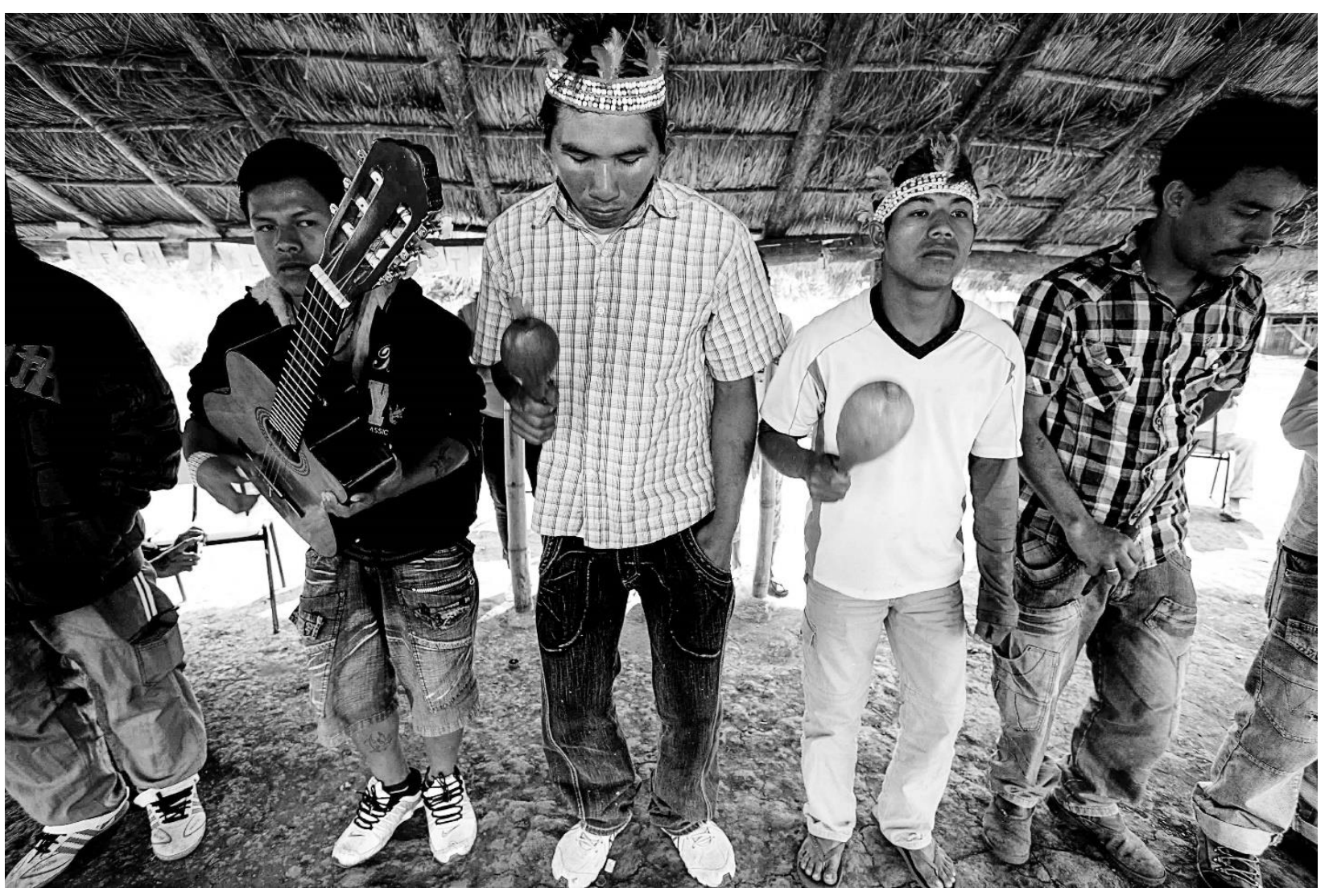

Reza no Tekoa Mirim - Município de Guaira 


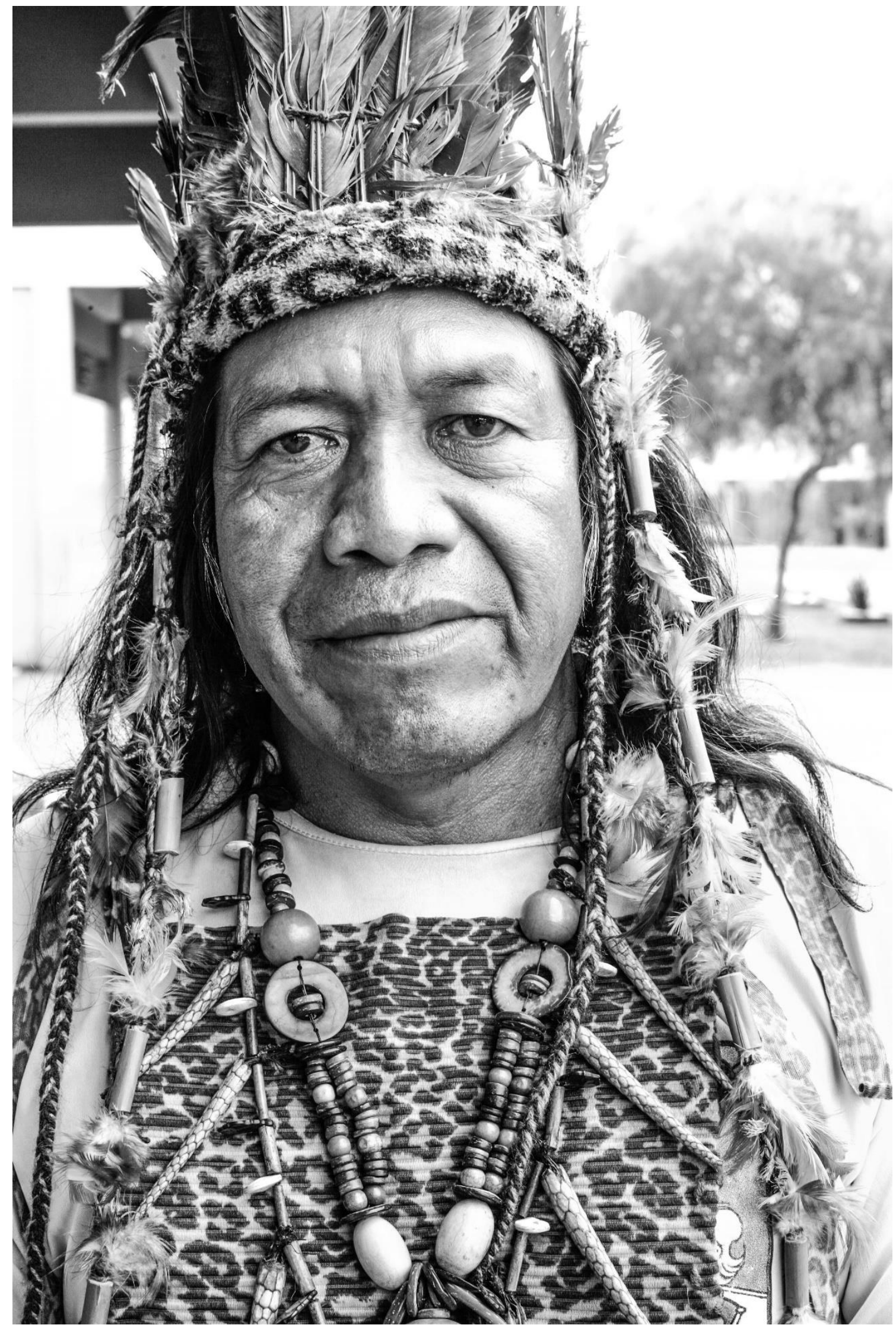

Xamõi Agostinho da comunidade Tekoa Añetete - Município de Diamente do Oeste 


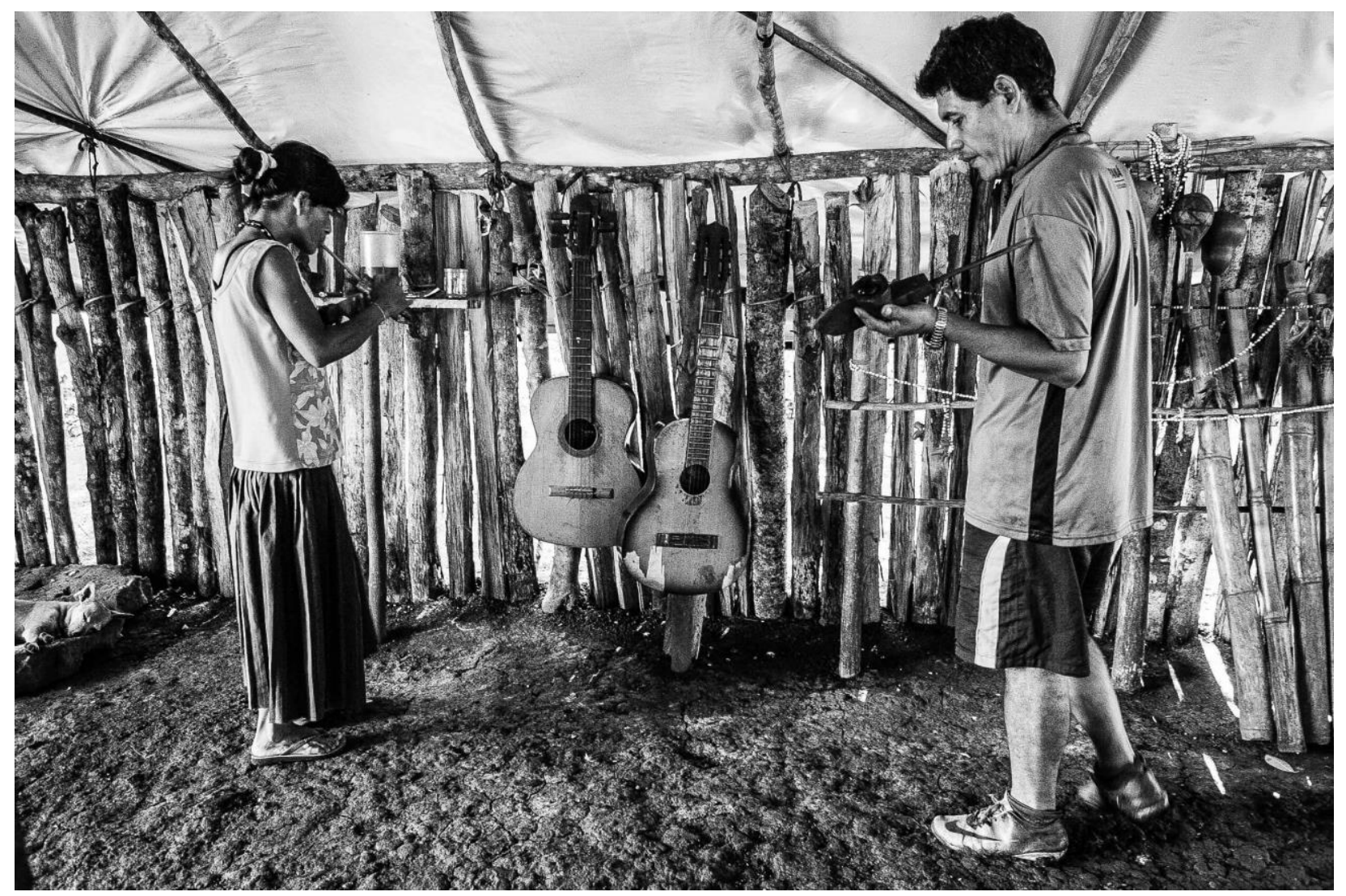

Xamõi Claudio Bogado e sua esposa em sua casa reza no Tekoa Mokoi Joegua - Município de Santa Helena 